Appleton has achieved renown in two spheres, either of which might be considered as forming a sufficiently full life for a lesser man of science. He has for more than a quarter of a century been the most active worker in the field of radio physics, and during this period he has conducted research work of the most far-reaching importance. Since 1939, also, he has been secretary of the Department of Scientific and Industrial Research, a position which gives him the responsibilities and duties of the leading man of science in the Government service of Britain. Appleton displayed his great scientific ingenuity and experimental skill in December 1924, when he demonstrated the existence of the Heaviside layer as an ionized region of the atmosphere capable of reflecting electromagnetic waves. Shortly afterwards, he discovered another and higher region-the Appleton layer-from which the shorter radio waves are reflected after they have penetrated the lower region. From that time onwards Appleton has conducted a continuous series of researches on the characteristics of the ionosphere, and the part they play in determining the mode of propagation of radio waves round the earth. The techniques developed in the course of these investigations provided the foundations for the development of radar in Great Britain, while the results of the research on the ionosphere have proved invaluable in forecasting and allocating the most suitable frequencies for practical radio communication, broadcasting and other applications. More recently, Sir Edward Appleton, in cooperation with other workers, has devoted attention to the reflexion of radio waves from meteors, and has demonstrated that sunspots are powerful sources of very short radio waves.

His work during the war years as secretary of the Department of Scientific and Industrial Research was particularly onerous for, in addition to conducting the normal activities of the Department, he was called upon in 1941 to advise the Government on the magnitude of the effort to be devoted to the exploitation of nuclear energy, and later to set up a special section of the Department to carry out the necessary research work forming the British contribution to the development of the atom bomb. Sir Edward, who was elected a fellow of the Royal Society in 1927, has received many honours and awards in Great Britain and overseas, and he has been president of the International Scientific Radio Union since 1934.

\section{Royal Society: Medal Awards}

His MAJESTy THE KING has approved the recommendations made by the Council of the Royal Society for the award of the two Royal Medals for the current year as follows :

Prof. C. N. Hinshelwood, Dr. Lee's professor of chemistry, University of Oxford, for his distinguished work on the mechanism of chemical reactions, from the simplest gas phase processes to the complexities of cell division ;

Dr. F. M. Burnet, director of the Walter and Eliza Hall Institute for Medical Research, Melbourne, for his distinguished work on bacteriophages, viruses and immunity; and for his contributions to the study of infectious disease as an ecological phenomenon.

The following awards of medals have been made by the President and Council of the Royal Society :

Copley Medal to Prof. G. H. Hardy, emeritus professor of pure mathematics, University of Cambridge, for his outstanding part in the development of mathematical analysis in Britain during the last thirty years ;

Davy Medal to Prof. L. C. Pauling, director of the Gates and Crellin Laboratories, California Institute of Technology, for his distinguished contributions to the theory of valency and for their application to systems of biological importance;

Buchanan Medal to Sir Edward Mellanby, secretary to the Medical Research Council, for his distinguished researches on the physiology of nutrition, especially in relation to the causation of deficiency diseases ;

Hughes Medal to Prof. J. F. Joliot, director of the National Centre of Scientific Research, Paris, for his distinguished contributions to nuclear physics, particularly the discovery of artificial radioactivity and of neutron emission in the fission process.

\section{Physiology at St. Thomas's Hospital Medical School: Prof. H. Barcroft}

Prof. Henry Baroroft, Dunville professor of physiology, Queen's University, Belfast, has recently been appointed to the University chair of physiology in St. Thomas's Hospital Medical School, London. Prof. Barcroft is a son of the late Sir Joseph Barcroft of Cambridge, and was educated at Marlborough College and King's College, Cambridge. He held the Harold Fry and George Henry Lewis studentships at Cambridge during 1927-29 and was awarded the Gedge Prize in 1930. He qualified in medicine at St. Mary's Hospital, London, after which he was appointed lecturer in physiology at University College, London, a post which he occupied from 1932 until 1935 . $\mathrm{He}$ has held the chair of physiology at Queen's University, Belfast, from 1935 until the present time, and has carried out distinguished work on the control of the vasomotor system, and of the blood flow to the limbs and other parts of the body. His experiments were mainly carried out on the human subject and involved important observations on the physiology of syncope.

\section{Jubilee of the Discovery of the Electron}

THE fiftieth anniversary of the discovery of the electron was recently marked in Cambridge by an open meeting of the Philosophical Society at which a lecture on the history of the Cavendish Laboratory was given by Dr. Alex. Wood in that Laboratory. Dr. Wood was himself a research student under Sir J. J. Thomson and has been closely associated with the teaching work of the Cavendish Laboratory since 1905. His lecture was illustrated by exhibits of historical apparatus used by Clerk Maxwell, Rayleigh, Thomson and Rutherford. Among guests present were Dr. G. F. C. Searle, who as a boy was shown round the Laboratory by Clerk Maxwell shortly after it was built; Mr. J. E. Rolph, who was appointed as laboratory assistant by Lord Rayleigh in 1881; Mr. F. J. Lincoln, who was a laboratory assistant for fifty-three years, including forty-two years as steward; Sir William Dampier, who as W. C. D. Whetham joined the Laboratory in the very early days of Sir J. J. Thomson's professorship ; and Lady Thomson, who as Miss Paget was a research student in 1889 and was married to J. J. Thomson in 1890 .

\section{British Books for Germany}

AT the Information Centres of the Control Commission in the British Zone of Germany reference books are available for those who live near enough; 